\title{
Identification of single nucleotide polymorphisms in the prion protein gene in Santa Ines and Dorset sheep ${ }^{1}$
}

\author{
Caroline P. Andrade ${ }^{2 *}$, José D. Barbosa Neto ${ }^{3}$ and David Driemeier ${ }^{2}$
}

\begin{abstract}
Andrade C.P., Barbosa Neto J.D. \& Driemeier D. 2018. Identification of single nucleotide polymorphisms in the prion protein gene in Santa Ines and Dorset sheep. Pesquisa Veterinária Brasileira 38(4):624-628. Setor de Patologia Veterinária, Faculdade de Veterinária, Universidade Federal do Rio Grande do Sul, Av. Bento Gonçalves 9090, prédio 42505, Porto Alegre, RS 91540-000, Brazil. E-mail: cacauandrade@yahoo.com.br

Scrapie is a transmissible spongiform encephalopathy (TSE) that affects sheep and goats and results from accumulation of the abnormal isoform of a prion protein in the central nervous system. Resistance or susceptibility to the disease is dependent on several factors, including the strain of infecting agent, the degree of exposure, and the presence of single nucleotide polymorphisms (SNPs) in the prion protein gene. The most important polymorphisms are present in codons 136,154 , and 171 . SNPs have also been identified in other codons, such as $118,127,141,142$, and 143 . The objective of this study was to investigate the genotypic profile of Santa Ines $(n=94)$ and Dorset $(n=69)$ sheep and identify polymorphisms in the prion protein gene using real-time PCR techniques and sequencing. We analyzed SNPs in 10 different codons $(127,136,138,140,141,142,143,154,171$, and 172 ) in Santa Ines sheep. Classification of the flock into risk groups associated with scrapie revealed that approximately $68 \%$ of the Santa Ines herd was considered at moderate risk (group 3), and the most frequent haplotype was ARQ/ARQ (47.8\%). For Dorset sheep, 42\% of the herd was considered at moderate risk (group 3), 40\% at low risk (group 2), and 12\% at very low risk (group 1). These findings improve our understanding of the genotype breed and further highlight the importance of genotyping and identification of polymorphisms in Brazilian herds to assess their effects on potential infections upon exposure to the sheep prion.
\end{abstract}

INDEX TERMS: Prion protein, sheep, single nucleotide, polymorphisms, genotyping.

\begin{abstract}
RESUMO.- [Identificação de polimorfismos de nucleotídeos únicos em ovinos Santa Inês e Dorset através do gene da proteína priônica.] Scrapie é uma encefalopatia espongiforme transmissível que afeta ovinos e caprinos, resultante do acúmulo de uma isoforma anormal da proteína priônica no sistema nervoso central. A resistência ou susceptibilidade está relacionada a diversos fatores, tais como, a cepa do agente infectante, o grau de exposição e o polimorfismo de nucleotídeo único (SNPs) do gene da proteína priônica. Os principais polimorfismos estão presentes nos códons 136, 154 e 171. SNPs também são identificadas em outros códons, tais como, 118, 127, 141, 142, e 143. 0 objetivo do trabalho foi descrever o perfil genotípico de um rebanho da

\footnotetext{
${ }^{1}$ Received on April 3, 2017.

Accepted for pubblication on April 12, 2017.

2 Setor de Patologia Veterinária, Departamento de Patologia Clínica Veterinária, Universidade Federal do Rio Grande do Sul, Av. Bento Gonçalves 9090, Porto Alegre, RS 91540-000, Brazil. *Corresponding author: cacauandrade@yahoo.com.br

${ }^{3}$ Centro Agropecuário, Departamento de Ciência Animal, Universidade Federal do Pará, Castanhal, PA, Brazil.
}

raça Santa Inês (n=94) e um rebanho da raça Dorset $(n=89)$ para identificar potenciais polimorfismos através da técnica de PCR em tempo real e sequenciamento. Os achados no rebanho Santa Inês indicaram a presença de polimorfismos de nucleotídeos únicos em 10 códons diferentes $(127,136$, $138,140,141,142,143,154,171$ e 172). A classificação do rebanho, quanto aos grupos de risco associados ao scrapie, relevaram que aproximadamente $68 \%$ dos ovinos foram considerados do grupo de risco moderado (grupo 3), onde o haplótipo mais frequente foi ARQ/ARQ (47,8\%). Para os ovinos da raça Dorset, $42 \%$ do rebanho foi considerado do grupo de risco moderado (grupo 3), 40\% do grupo de risco baixo (grupo 2) e 12\% do grupo de risco muito baixo. Os dados encontrados contribuem para o conhecimento do genótipo das raças, destacando a importância de trabalhos que relatam os polimorfismos genéticos para a identificação de rebanhos brasileiros, bem como o seu impacto a infecções com exposição ao príon ovino.

TERMOS DE INDEXAÇÃO: Proteína priônica, ovinos, polimorfismos, nulceotídeos únicos, genotipagem. 


\section{INTRODUCTION}

The enzootic paraplegia of sheep, or scrapie, is a fatal, progressive neurodegenerative disease belonging to the group of transmissible spongiform encephalopathies (TSEs). Scrapie affects sheep and goats and may be related to bovine spongiform encephalopathy (BSE or "mad cow disease"). The transmissible agent for scrapie is a prion, the abnormal isoform $\mathrm{PrP}^{\mathrm{Sc}}(\mathrm{Sc}=$ scrapie), resulting from a conformational change in the normal protein encoded by the host and deposited in the central nervous system (Prusiner 1982, Parnham et al. 2001).

A method used in many countries for scrapie control is genetic improvement based on selection of animals with greater resistance to the clinical disease (Houston et al. 2002, Hickford et al. 2008). The selection is based on analysis of single nucleotide polymorphisms (SNPs) present in the prion protein gene. The main codons analyzed are 136,154 , and 171. At these three codons, sheep with an ARR/ARR genotype are considered the most resistant to infection whereas the VRQ/VRQ genotype is considered the most susceptible. In Brazil, cases of scrapie have been observed in the Hampshire Down, Suffolk, Dorper, and Santa Ines sheep breeds, (so-called "face-black" breeds), which predominantly exhibited susceptible genotypes (Passos et al. 2008, Andrade etal. 2011, 2012, 2015, Ianella et al. 2012). In a genotyping study of 58 scrapie-free Santa Ines sheep in Brazil, approximately $50 \%$ of the herd was considered susceptible to scrapie (Lima et al. 2007).

In addition to the aforementioned major codons, several studies describe the importance of identifying polymorphisms in other codons in the prion protein gene, which may be involved in resistance or susceptibility to infection. For example, the heterozygous allele at codon 143 (HR) has been suggested to be associated with partial protection in naturally infected goats (Billinis et al. 2002). This study concluded that the proportion of goats affected was higher for the homozygous genotype than for the heterozygous genotype. Another example is a polymorphism at codon 142 , which is associated with an increase in the incubation period of the disease in sheep and goats affected with scrapie (Goldmann et al. 1996). In addition, other polymorphisms have been identified, with or without known functions, such as codon 141 (atypical scrapie) and codons 112, 127, 137, 138, 143, 172 and 176 (DeSilva et al. 2003, Acin et al. 2004, Lima et al. 2007, Benestad et al. 2008, Maestrale et al. 2009, Vaccari et al. 2009).

In Brazil, there is no genetic improvement program for the prevention of scrapie. Although some initiatives do exist, such as the creation of a voluntary certification program of herds and genetic susceptibility testing for scrapie, these are still at a preliminary stage. This study aims to genotype a flock of Santa Ines and Dorset sheep, through of prion protein gene, to improve our understanding of the genotypic profile of each breed which can be used in future breeding programs. Additionally, we classify the herd according to the risk groups described by Dawson et al. (2008).

\section{MATERIALS ANS METHODS}

DNA extraction, PCR, and sequencing. Whole blood samples of Santa Ines sheep $(n=94)$ and Dorset sheep $(n=69)$ were collected in a property free of scrapie (no clinical history), in northern and southern Brazil, respectively. Blood samples were obtained using
BD Vacutainer EDTA tubes and stored at $-20^{\circ} \mathrm{C}$ until further analysis. Genomic DNA was extracted from $200 \mu \mathrm{L}$ whole blood using the QIAmp Mini Kit (Qiagen) according to the manufacturer's instructions.

Genotyping by real-time PCR for the three major codons $(136,154$, and 171) was performed using methods previously described by our group (Andrade et al. 2012). The sequencing reaction was performed using a forward primer flanking the region of codon 136 (5'-ATGAAGCATGTGGCAGGAGC- $3^{\prime}$ ) and a reverse primer flanking the region of codon 171 ( $5^{\prime}$-GGTGACTGTGTGTTGCTTGACTG-3') at 245-bp fragment containing the major regions of the codons analyzed for susceptibility to scrapie (l'Homme et al. 2008). The PCR product was purified using a Purelink ${ }^{\circledR}$ kit (Invitrogen ${ }^{\mathrm{TM}}$ ), quantitated with a Qubit $^{\circledR}$ kit (Invitrogen ${ }^{\mathrm{TM}}$ ) according to manufacturer's instructions, and sequenced using the BigDye Terminator (version 3.1) on an ABI PRISM 3130 Genetic Analyzer. Each sample was independently sequenced using a forward and reverse primer set. Consensus sequences were determined using the Staden software package version 1.7.0 (Staden et al. 2003) along with the Phred program with a score of 20 min (Ewing \& Green 1998, Ewing et al. 1998), and novoSNP version 3.0.1 software (Weckx et al. 2005).

Data analysis. The genotyping data were analyzed by genotype frequency of the herd, which was calculated based on the formula $\left(\mathrm{f}_{\mathrm{ij}}=\mathrm{n}_{\mathrm{ij}} / \mathrm{N}\right)$, where $\mathrm{f}_{\mathrm{ij}}$ represents the frequency of the genotype $\mathrm{ij}, \mathrm{n}_{\mathrm{ij}}$ is the number of animals showing the ij genotype, and $\mathrm{N}$ corresponds to the total number of animals analyzed, as described by Sotomaior et al. (2008). In addition, the analyzed herd was classified according to the risk groups for susceptibility, as described by Dawson et al. (2008).

\section{RESULTS}

Genotyping of the Santa Ines and Dorset sheep was performed for codons 136, 154, and 171, by real-time PCR and sequencing. Additionally, sequencing of the prion protein gene allowed for the analysis of possible polymorphisms at 15 codons. Figure 1 shows single nucleotide polymorphisms in different codons: $127,136,138,140,141,142,143,154,171$, and 172 . Figure 2 shows the haplotype frequencies according to the risk groups for susceptibility, as described by Dawson et al. (2008).

For Santa Ines sheep, codon 127 showed four polymorphisms with a frequency of $70.2 \%, 19.1 \%, 9.6 \%$, and $1.1 \%$ for genotypes GG, GS, GA, and SS, respectively. The polymorphism at codon 138 was at a frequency of $1.1 \%$ for the SC genotype. For codon $140,3.2 \%$ of the herd showed the heterozygous genotype PL. At codon 142, the frequency of the IT genotype was $6.4 \%$. A higher frequency was found at codon 143 with $10.6 \%$ of the herd having the HR genotype (Fig.1A). In addition to these polymorphisms, we identified the LF genotype $(1.1 \%)$ at codon 141 in one sheep (ARQ/ARQ), which is associated with the atypical form of scrapie. The same sheep also showed a polymorphism at codon 127 with the heterozygous genotype of YD (5.3\%). In samples with polymorphisms, it was found that nine sheep had polymorphisms in two codons different, eight had to change at codon 127 (Fig.1A).

The analysis of genotypes in the three main codons in Santa Ines sheep $(136,154$, and 171), showed a frequency of $96.8 \%$ for the AA genotype and $3.2 \%$ for the AV genotype at codon 136. At codon 154, the $\mathrm{HH}$ and RH genotypes showed a frequency of $83 \%$ and $17 \%$, respectively. At codon 171 , frequencies of $62.8 \%, 25.6 \%, 7.4 \%$, and $4.2 \%$ were observed for the genotypes QQ, QR, RR, and QH, respectively (Fig.1A). Characterizing the haplotypes in terms of risk groups, as described by Dawson et al. (2008), revealed that approximately 


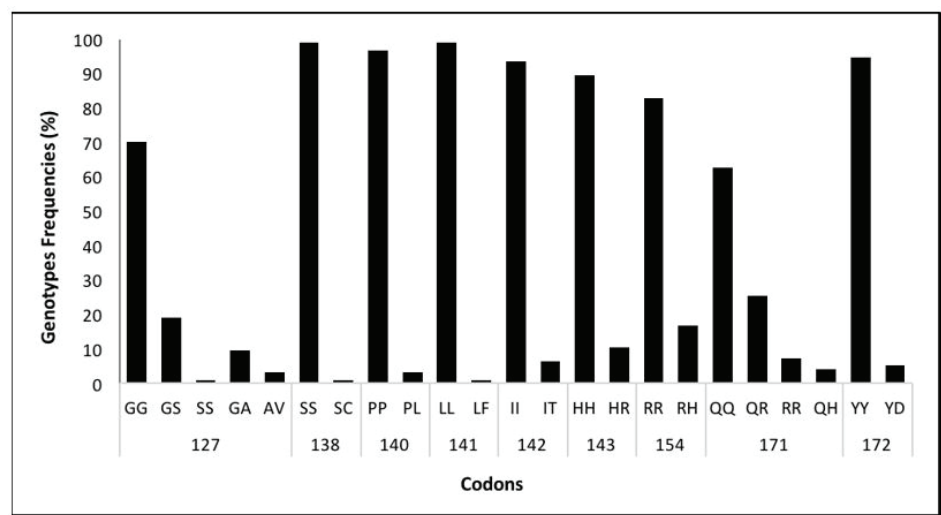

(A)

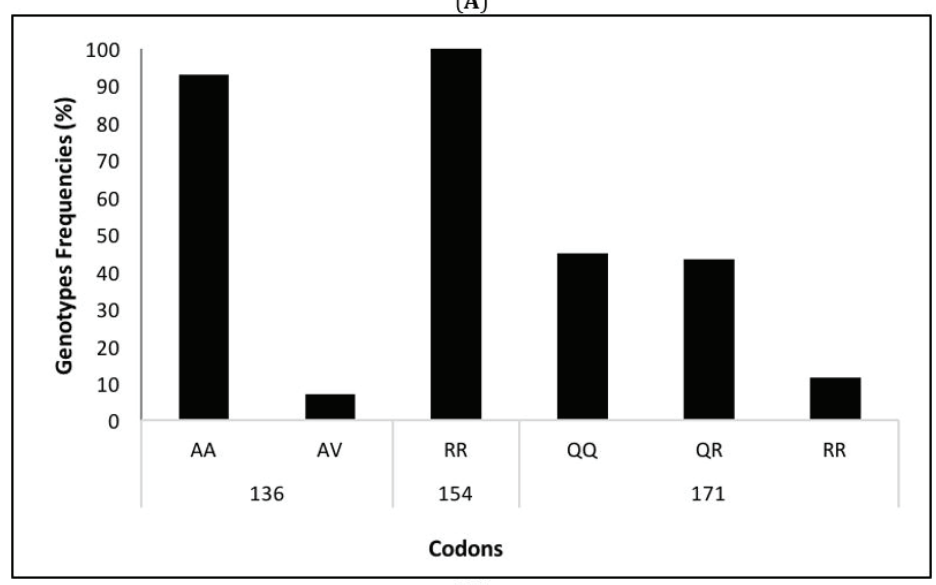

(B)

Fig.1. (A) Genotypic frequency of codons of the PRNP gene in Santa Ines sheep ( $n=94$ samples). (B) Dorset (n=69) sheep. Samples evaluated by real-time PCR and sequencing.

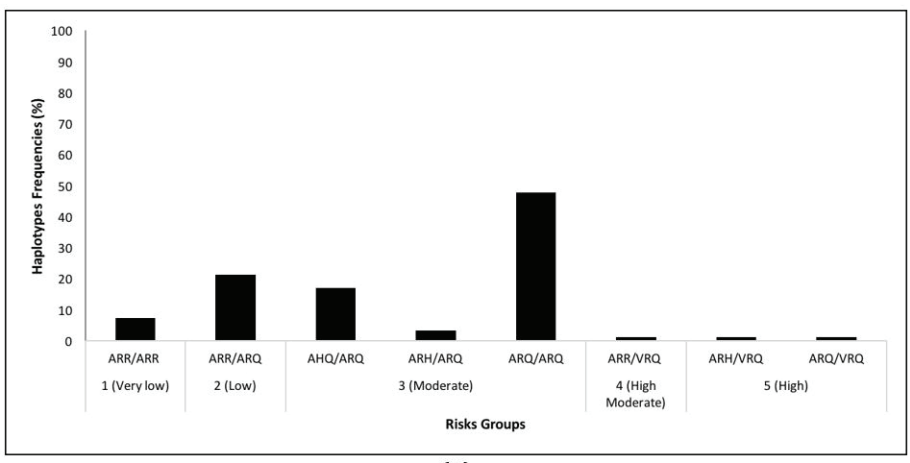

(A)

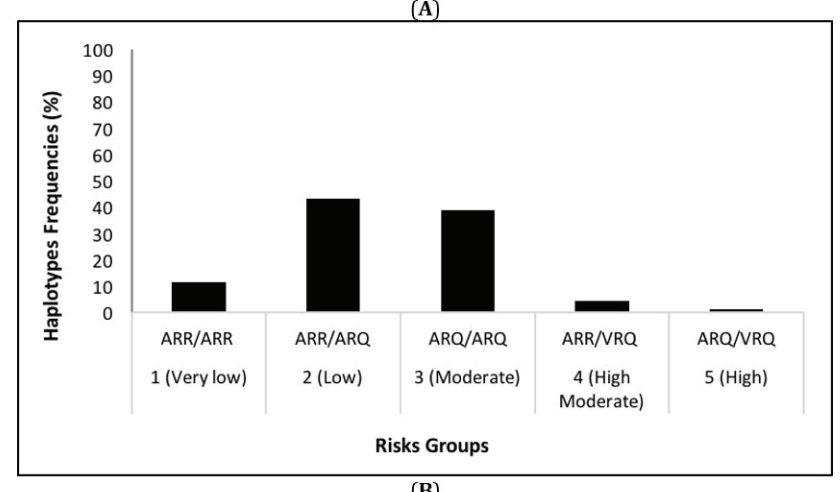

Fig.2. (A) Frequency of haplotypes in Santa Ines sheep ( $n=94$ sheep). (B) Dorset sheep ( $n=69)$, in relation to risk groups susceptibility to scrapie, described by Dawson et al. (2008). Group $1=$ very low risk, group $2=$ low risk, group $3=$ moderate risk, group $4=$ high moderate risk, group $5=$ high risk. 
$7.4 \%$ of the herd was at very low risk (ARR/ARR, group 1), $21.3 \%$ was at low risk (ARRR/ARQ, group 2), and 68\% at moderate risk (AHQ/ARQ, ARH/ARQ, ARQ/ARQ, group 3). In this group, the ARQ/ARQ genotype was the most frequent (47.8\%), followed by AHQ/ARQ genotype with 17\%. Only $1.1 \%$ of the flock belonged at moderate high risk (ARR/VRQ, group 4 ), and $2.2 \%$ was considered high risk (ARH/VRQ, ARQ/VRQ, group 5) (Fig.2A).

For Dorset sheep, we performed genotyping using real-time PCR. We found a frequency of $94 \%$ for the AA genotype and $6 \%$ for the AV genotype at codon 136 . At codon 154, the frequency was $100 \%$ for the RR genotype. At codon 171 , the frequencies were $45 \%, 43 \%$, and $12 \%$ for the genotypes QR, QQ, and RR, respectively (Fig.1B). Classification of the Dorset sheep into risk groups showed that $11.6 \%$ of the herd was at very low risk (ARR/ARR, group 1), 43.5\% was at low risk (ARR/ARQ, group 2), 39.1\% was at moderate risk (ARQ/ARQ, group 3), $4.3 \%$ was at moderate high risk (ARR/VRQ, group 4 ), and $1.5 \%$ was at high risk (ARQ/VRQ, group 5) (Fig.2B).

\section{DISCUSSION}

In this study, we analyzed the genotypes of Santa Ines and Dorset sheep in Brazil to determine their risk for scrapie, a fatal disease caused by a prion protein. And polymorphisms considered "rare" were identified in the study herd, specifically at codons $127,138,140,141,142,143$, and 172 of the prion protein gene. Previous studies found polymorphisms at five of these codons in another Santa Ines flock of sheep in Brazil (Lima et al. 2007). We compared the frequency of genotypes between the two studies and found the frequencies to be similar $(\sim 1.1 \%)$ at codon 127 . However, in our study, we found other genotypic forms present at this codon ( GS $=19.1 \%$ and GA $=9.6 \%$ ). The polymorphism at codon 138 found by Lima et al. (2007) modified the amino acid serine to asparagine; this differs from our results; we found that serine was modified to cysteine, which has not been previously described. At codon 141, considered to be involved in atypical scrapie, the frequency found by Lima et al. (2007) was higher $(5.2 \%)$ than that found in our study. Interestingly, another study found two Santa Ines sheep with the same polymorphism (Ianella et al. 2012). At codons 142 and 143, the frequencies found in our study were $6.4 \%$ and $10.3 \%$, respectively. These frequencies are higher than those found by Lima et al. (2007), who reported $1.7 \%$ for both codons. Finally, at codon 172, the frequency (5.3\%) was lower than that reported by Lima et al. (2007).

By analyzing the main codons $(135,154$, and 171$)$ involved with susceptibility to scrapie compared to other Santa Ines herds, we find that the genotype with the highest percentage is ARQ/ARQ at $47.8 \%$. This is similar to other studies that reported ARQ/ARQ to be at frequencies of 43\% and 56.7\% (Sotomaior et al. 2008, Santos et al. 2012). The second most common genotype was ARQ/ARR at a frequency of $21.3 \%$. This can be compared to the percentage found by Sotomaior et al. (2008) at 29\%. Two other studies found approximately $32.2 \%$ and $10.1 \%$ of sheep with this genotype (Ianella et al. 2012, Santos et al. 2012). Finally, the third most prevalent genotype was AHQ/ARQ corresponding to $17 \%$ of cases, a percentage that is consistent with the results of previous studies (Ianella et al. 2012).
When the Santa Ines herd was evaluated for risk groups and compared with previous reports, we found that $71.3 \%$ of the sheep were considered at moderate risk for scrapie, with approximately $8 \%$ belonging to group 3 , and the remaining belonging to groups 4 and 5 . These data are similar to those described by Santos et al. (2012). In another study, it was found that approximately $90 \%$ of sheep belonged to risk groups 2 and 3 (Ianella et al. 2012).

We analyzed the genotypes at the major codons $(135,154$, and 171) in Dorset sheep and compared the results with previous work (DeSilva et al. 2003). Between these two studies, the percentages of the AA and AV genotypes at codon 136 and codon 154 were similar. The QQ and QR genotypes at codon 171 also had the same percentage in the two studies. One main difference between these studies was that the resistant genotype, RR, was found at $12 \%$ in our study as against 8\% reported in the work of DeSilva et al. (2003). The Dorset herd analyzed in our study was composed of more resistant sheep (ARR/ARR) than were other Brazilian herds, being at percentages of $12 \%$ and $6 \%$, respectively (Sotomaior et al. 2008). The main haplotype of the risk groups was ARR/ARQ, which is at low risk (43.5\%, group 2); this varies from the results reported by Sotomaior et al. (2008) which found $56 \%$ of the herd was at moderate risk (group 3). Their study also revealed that $6 \%$ of the sheep belonged to group 5 (ARQ/VRQ, high risk), whereas we found only $1.5 \%$ of the herd to be at high risk.

These data reinforce the need to more extensively genotype Santa Ines and Dorset sheep to determine a more accurate genotypic profile among the flocks. We hypothesize that Santa Ines and Dorset sheep are susceptible to scrapie because the percentage of susceptible sheep is higher in herds analyzed in our work, as well as in previously published studies. Furthermore, these findings can be used as a basis for future disease control programs aimed at genetic improvement through artificial selection.

Acknowledgements.- The authors would like to thank all of their collaborators, in especial Professor José Diomedes Barbosa Neto, Universidade Federal do Pará. The first author (Andrade C.P.) was supported by a fellowship from Conselho Nacional de Desenvolvimento Científico e Tecnológico (CNPq, Proc. 162567/2013-8)

\section{REFERENCES}

Acín C., Martín-Burriel I., Goldmann W., Lyahyai J., Monzón M., Bolea R., Smith A., Rodellar C., Badiola J.J. \& Zaragoza P. 2004. Prion protein gene polymorphisms in healthy and scrapie-affected Spanish sheep. J. Gen. Virol. 85(Pt 7):2103-2110. http://dx.doi.org/10.1099/vir.0.80047-0. PMid:15218196.

Andrade C.P., Almeida L.L., Castro L.A., Driemeier D. \& Silva S.C. 2012 Development of a real-time polymerase chain reaction assay for single nucleotide polymorphism genotyping codons 136,154 , and 171 of the prnp gene and application to Brazilian sheep herds. J. Vet. Diagn. Invest. 25(1):120 124. http://dx.doi.org/10.1177/1040638712471343. PMid:23345274.

Andrade C.P., Almeida L.L., Castro L.A., Leal J.S., Silva S.C. \& Driemeier D. 2011 Single nucleotide polymorphisms at 15 codons of the prion protein gene from a scrapie-affected herd of Suffolk sheep in Brazil. Pesq. Vet. Bras. 31(10):893-898. http://dx.doi.org/10.1590/S0100-736X2011001000010.

Andrade C.P., Oliveira E.C., Leal J.S., Almeida L.L., Castro L.A., Silva S.C. \& Driemeier D. 2015. Report of outbreaks of classical scrapie in Dorper 
sheep and associated prion protein gene polymorphisms in affected flocks. Trop. Anim. Health Prod. 47(6):1203-1212. http://dx.doi.org/10.1007/ s11250-015-0849-9. PMid:25995150.

Benestad S.L., Arsac J.N., Goldmann W. \& Noremark M. 2008. Atypical/Nor98 scrapie: properties of the agent, genetics, and epidemiology. Vet. Res. 39(4):19. http://dx.doi.org/10.1051/vetres:2007056. PMid:18187032.

Billinis C., Panagiotidis C.H., Psychas V., Argyroudis S., Nicolaou A., Leontides S., Sklaviadis T. \& Papadopoulos 0. 2002. Prion protein gene polymorphisms in natural goat scrapie. J. Gen. Virol. 83(Pt 3):713-721. http://dx.doi. org/10.1099/0022-1317-83-3-713. PMid:11842266.

Dawson M., Moore R.C. \& Bishop S.C. 2008. Progress and limits of PrP gene selection policy. Vet. Res. 39(4):25-36. http://dx.doi.org/10.1051/ vetres:2007064. PMid:18258168.

DeSilva U., Guo X., Kupfer D.M., Fernando S.C., Pillai A.T., Najar F.Z., So S., Fitch G.Q. \& Roe B.A. 2003. Allelic variants of ovine prion protein gene (PRNP) in Oklahoma sheep. Cytogenet. Genome Res. 102(1-4):89-94. http://dx.doi. org/10.1159/000075731. PMid:14970685.

Ewing B. \& Green P. 1998. Base-calling of automated sequencer traces using phred. II. Error probabilities. Genome Res. 8(3):186-194. http://dx.doi. org/10.1101/gr.8.3.186. PMid:9521922.

Ewing B., Hillier L., Wendl M.C. \& Green P. 1998. Base-calling of automated sequencer traces using phred. I. Accuracy assessment. Genome Res. 8(3):175-185. http://dx.doi.org/10.1101/gr.8.3.175. PMid:9521921.

Goldmann W., Martin T., Foster J., Hughes S., Smith G., Hughes K., Dawson M. \& Hunter N. 1996. Novel polymorphisms in the caprine PrP gene: a codon 142 mutation associated with scrapie incubation period. J. Gen. Virol. 77(Pt 11):2885-2891. http://dx.doi.org/10.1099/0022-1317-7711-2885. PMid:8922485.

Hickford J.G.H., Zhou H., Fang Q., Byun S.O. \& Gong H. 2008. Frequency of PRNP genotypes in common New Zealand sheep breeds. Vet. Rec. 163(15):453454. http://dx.doi.org/10.1136/vr.163.15.453. PMid:18849578.

Houston E.F., Jeffrey M., Halliday S.I., Hunter N. \& Goldmann W. 2002. New Zealand sheep with scrapie-susceptible PrP genotypes succumb to experimental challenge with a sheep-passaged scrapie isolate (SSBP/1). J. Gen. Virol. 83(Pt 5):1247-1250. http://dx.doi.org/10.1099/0022-131783-5-1247. PMid:11961280.

Ianella P., McManus C.M., Caetano A.R. \& Paiva S.R. 2012. PRNP haplotype and genotype frequencies in Brazilian sheep: issues for conservation and breeding programs. Res. Vet. Sci. 93(1):219-225. http://dx.doi.org/10.1016/j. rvsc.2011.06.025. PMid:21816449.
L'Homme Y., Leboeuf A. \& Cameron J. 2008. PrP genotype frequency of Quebec sheep breeds determined by real-time PCR and molecular beacons. Can. J. Vet. Res. 72(4):320-324. PMid:18783020.

Lima A.C., Bossers A., Souza C.E., Oliveira S.M. \& Oliveira D.M. 2007. Prp genotypes in a pedigree flock of a Santa Inês sheep. Vet. Rec. 160(10):336337. http://dx.doi.org/10.1136/vr.160.10.336. PMid:17351175.

Maestrale C., Carta A., Attene S., Galistu A., Santucciu C., Cancedda M.G., Saba M., Sechi S., Patta C., Bandino E. \& Ligios C. 2009. p.Asn176Lys and p.Met137Thr dimorphisms of the PRNP gene significantly decrease the susceptibility to classical scrapie in ARQ/ARQ sheep. Anim. Genet. 40(6):982-985. http:// dx.doi.org/10.1111/j.1365-2052.2009.01943.x. PMid:19706028.

Parnham D., Chong A., Hunter N., Foster J. \& Goldmann W. 2001. Partial dissociation of PrPSc deposition and vacuolation in the brains of scrapie and BSE experimentally affected goats. J. Gen. Virol. 82(Pt 1):267-273. http://dx.doi.org/10.1099/0022-1317-82-1-267. PMid:11125179.

Passos D.T., Ribeiro L.A.O., Rodrigues N.C., Hepp D. \& Weimer T.A. 2008. PrP polymorphisms in Brazilian sheep. Small Rumin. Res. 74(1-3):130-133. http://dx.doi.org/10.1016/j.smallrumres.2007.04.008.

Prusiner S.B. 1982. Novel proteinaceous infectious particles cause scrapie. Science 216(4542):136-144. http://dx.doi.org/10.1126/science.6801762. PMid:6801762.

Santos C.R., Mori E., Leao D.A. \& Maiorka P.C. 2012. Genotipagem de polimorfismos no gene prnp em ovinos da raça Santa Inês no Estado de São Paulo. Pesq. Vet. Bras. 32(3):221-226. http://dx.doi.org/10.1590/ S0100-736X2012000300007.

Sotomaior C.S., Sotomaior V.S., Madeira H.M.F. \& Thomaz-Soccol V. 2008. Prion protein gene polymorphisms in sheep in the state of Parana, Brazil. Anim. Genet. 39(6):659-661. http://dx.doi.org/10.1111/j.13652052.2008.01775.x. PMid:18752582.

Staden R., Judge D.P. \& Bonfield J.K. 2003. Managing sequencing projects in the GAP4 environment, p.327-344. In: Krawetz S.A. \& Womble D.D. (Eds), Introduction to Bioinformatics: a theoretical and practical approach. Human Press Inc., NJ 07512, New York.

Vaccari G., Scavia G., Sala M., Cosseddu G., Chiappini B., Conte M., Esposito E., Lorenzetti R., Perfetti G., Marconi P., Scholl F., Barbaro K., Bella A., Nonno R. \& Agrimi U. 2009. Protective effect of the AT137RQ and ARQK176 PrP allele against classical scrapie in Sarda breed sheep. Vet. Res. 40(3):19-29. http://dx.doi.org/10.1051/vetres/2009002. PMid:19171116.

Weckx S., Del-Favero J., Rademakers R., Claes L., Cruts M., De Jonghe P., Van Broeckhoven C. \& De Rijk P. 2005. novoSNP, a novel computational tool for sequence variation discovery. Genome Res. 15(3):436-442. http://dx.doi. org/10.1101/gr.2754005. PMid:15741513. 